University of Nebraska - Lincoln

DigitalCommons@University of Nebraska - Lincoln

Textile Society of America Symposium

Proceedings

$10-2020$

\title{
Inscription, Iconography, and the Individual: A Late Antique Textile from the Harvard Art Museums in Context
}

Katherine M. Taronas

Follow this and additional works at: https://digitalcommons.unl.edu/tsaconf

Part of the Art and Materials Conservation Commons, Art Practice Commons, Fashion Design Commons, Fiber, Textile, and Weaving Arts Commons, Fine Arts Commons, and the Museum Studies Commons

This Article is brought to you for free and open access by the Textile Society of America at DigitalCommons@University of Nebraska - Lincoln. It has been accepted for inclusion in Textile Society of America Symposium Proceedings by an authorized administrator of DigitalCommons@University of Nebraska - Lincoln. 


\section{Inscription, Iconography, and the Individual: A Late Antique Textile from the Harvard Art Museums in Context}

Katherine M. Taronas

ktaronas@g.harvard.edu

Byzantine weaving is known for its pictorial tradition - for complex tapestry compositions filled with human and animal figures. Woven inscriptions appear most often in this context as labels that fix the identities of persons represented, especially in cases where iconography might otherwise leave identity ambiguous. ${ }^{1}$ However, a small group of Early Byzantine weavings from Egypt dating between the fourth and sixth centuries use text in an entirely different manner, one that fits within the tradition of protective amuletic inscriptions widespread in the ancient and Byzantine worlds but whose survival on textiles is rare. ${ }^{2}$ These textiles combine personal names with amuletic signs and symbols to invoke divine aid for specific individuals.

This paper introduces this set of textiles as a group to raise the issue of their unique approach to word and image and their place within the Byzantine tradition of magical and potent objects. It also assembles this group to contextualize a remarkable Early Byzantine textile in the collection of the Harvard Art Museums (acc. no. 1975.41.28) that will feature in the upcoming exhibition Social Fabrics: Inscribed Textiles from Medieval Egyptian Tombs as an example of woven text from the pre-Islamic era in Egypt. ${ }^{3}$ The text on this piece-consisting of paired inscriptions and elaborated letterforms that serve as Christian symbols - creates an instructive comparison to the role of inscriptions on Islamic tiraz, as both are often meant to communicate blessings to their owner but achieve this transmission of blessing through different textual strategies. The text on this early textile, made in the fifth century or first half of the sixth, acts as talisman, marshaling a selection of protective and magical signs for the benefit of the individual named in the inscriptions.

The textile under consideration is noteworthy for its size ( $873 / 16 \times 581 / 4$ in) and for its relative completeness. The vast majority of Late Antique textiles survive as fragments due to early collecting and excavation practices that favored preservation only of the areas of tapestry ornamentation. The original textile now consists of two halves sewn together by a modern seam. A small area of fabric could conceivably have been excised along this join, but if any material was lost it appears to have been minimal.

\footnotetext{
${ }^{1}$ An overview of the character of inscriptions on Byzantine-era Egyptian weavings can be found in an excellent article by Jacques Van der Vliet: “'In a Robe of Gold': Status, Magic and Politics on Inscribed Christian Textiles from Egypt," in Textile Messages: Inscribed Fabrics from Roman to Abbasid Egypt, ed. Cäcilia Fluck and Gisela Helmecke (Leiden: Brill, 2006), 23-67. His primary subject is the nature of woven inscriptions on Coptic tiraz-style textiles.

${ }^{2}$ Henry Maguire, ed., Byzantine Magic (Washington, DC: Dumbarton. Oaks Research Library and Collection 1995); Jeffrey Spier, "Medieval Byzantine Magical Amulets and Their Tradition," Journal of the Warburg and Courtauld Institutes 56 (1993): 25-62; Fritz Graf, Magic in the Ancient World, trans. Franklin Philip (Cambridge, MA: Harvard University Press, 1997).

${ }^{3}$ This textile is cat. no. 24 in the forthcoming exhibition catalog Social Fabrics: Inscribed Textiles from Medieval Egyptian Tombs, ed. Mary McWilliams (Cambridge, MA: Harvard Art Museums, 2021). The exhibition will open at the Harvard Art Museums in January 2022.
} 
The large fields of loop pile — some of it in rows of blue, green, and red — suggest that this was once a warm and soft furnishing textile, though its precise function remains uncertain. Its final use as a burial shroud is evident from the extensive staining concentrated on one half of the fabric.

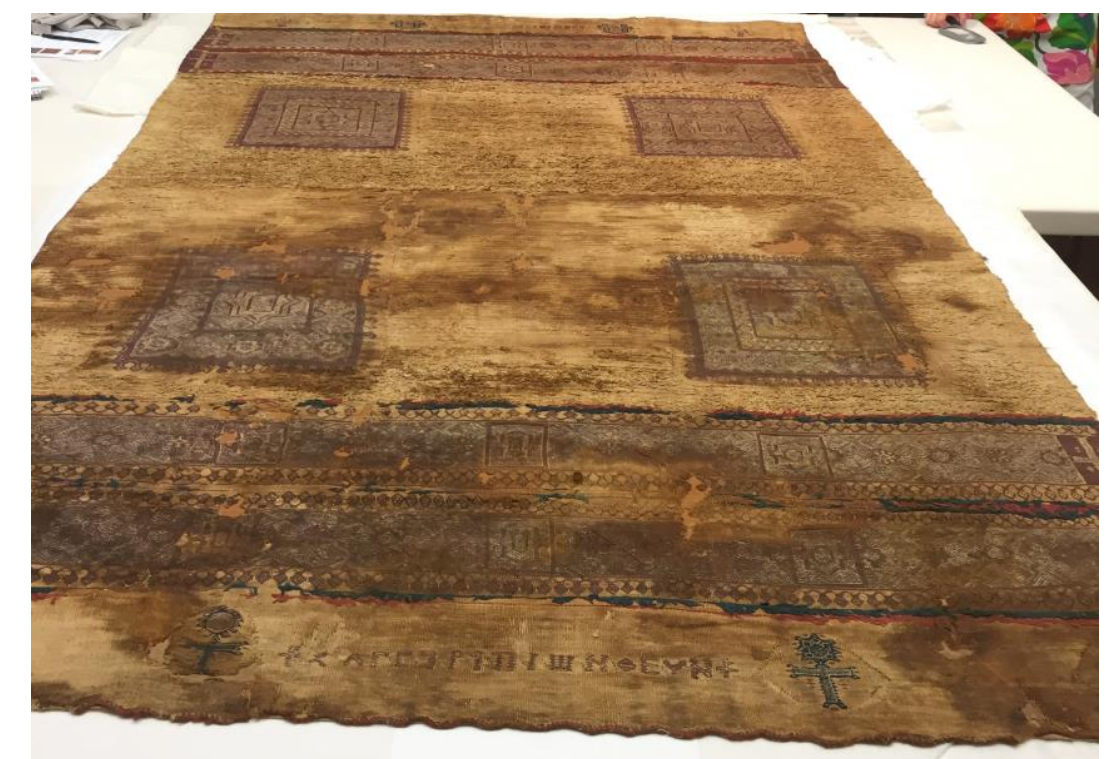

Textile shroud, Early Byzantine, from Egypt, $5^{\text {th }}-6^{\text {th }}$ century CE, linen and wool, Harvard Art Museum 1975.41.28, Gift of The Hagop Kevorkian Foundation in memory of Hagop Kevorkian, photo by author

The object is richly ornamented, though no obviously figural decoration appears. Geometric pattern and interlace, illustrated below in detail photographs, provide embellishment, as do the symbolic textual elements its weavers elaborated into almost pictorial devices.

Supplementary weft yarns form delicate webs of interlace patterning against the purple weftfaced bands and squares that divide up the textile's surface. Intricate designs like these may have been considered apotropaic, with spiraling, knotted, and complicated shapes thought to entrap evil forces and deflect the harmful power of the Evil Eye. ${ }^{4}$
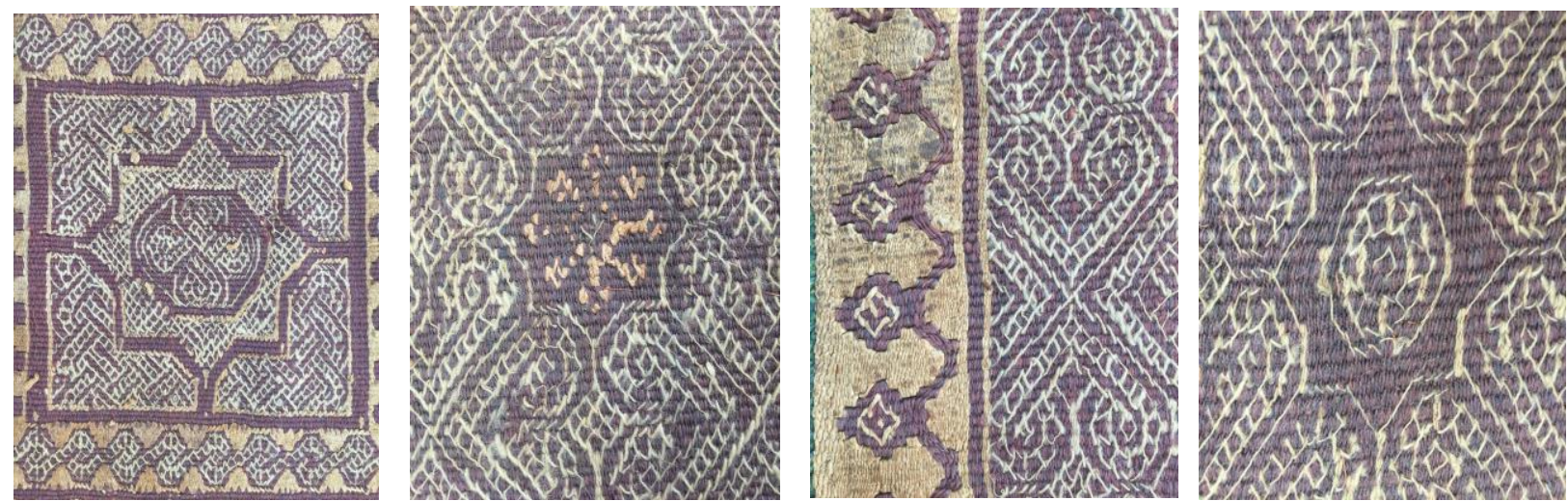

Details of supplementary weft wrapping on textile shroud, Early Byzantine, from Egypt, $5^{\text {th }}-6^{\text {th }}$ century CE, linen and wool, Harvard Art Museum 1975.41.28, Gift of The Hagop Kevorkian Foundation in memory of Hagop Kevorkian, photos by author

\footnotetext{
${ }^{4}$ Jennifer Ball, "Charms: Protective and Auspicious Motifs," in Designing Identity: The Power of Textiles in Late Antiquity, ed. Thelma K. Thomas (Princeton: Princeton University Press, 2016), 54-65.
} 
At both ends of the textile are nearly identical Greek inscriptions that I argue bear an apotropaic function similar to that of the interlace webs.

Though both inscriptions have the same orientation, the 'upper' inscription is truncated and lacks the final characters found in the other, suggesting an error on the part of the weaver. The beginnings and ends of the inscriptions are marked with staurograms, a ligature of the Greek

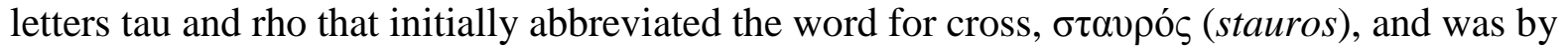
this time viewed as a symbol of Christ. Larry Hurtado argues that the staurogram was the first Christian visual image, appearing in second-century New Testament manuscripts and predating any extant Christian works of art. ${ }^{5}$ The sign could be understood by viewers both as a textual abbreviation and as a highly simplified pictorial representation of the crucified Christ, resembling in its contours the most basic outline of a body suspended on a cross. The staurogram sign in itself thus embodies an interplay between the visual and the textual that pervades the iconographic scheme of this textile.

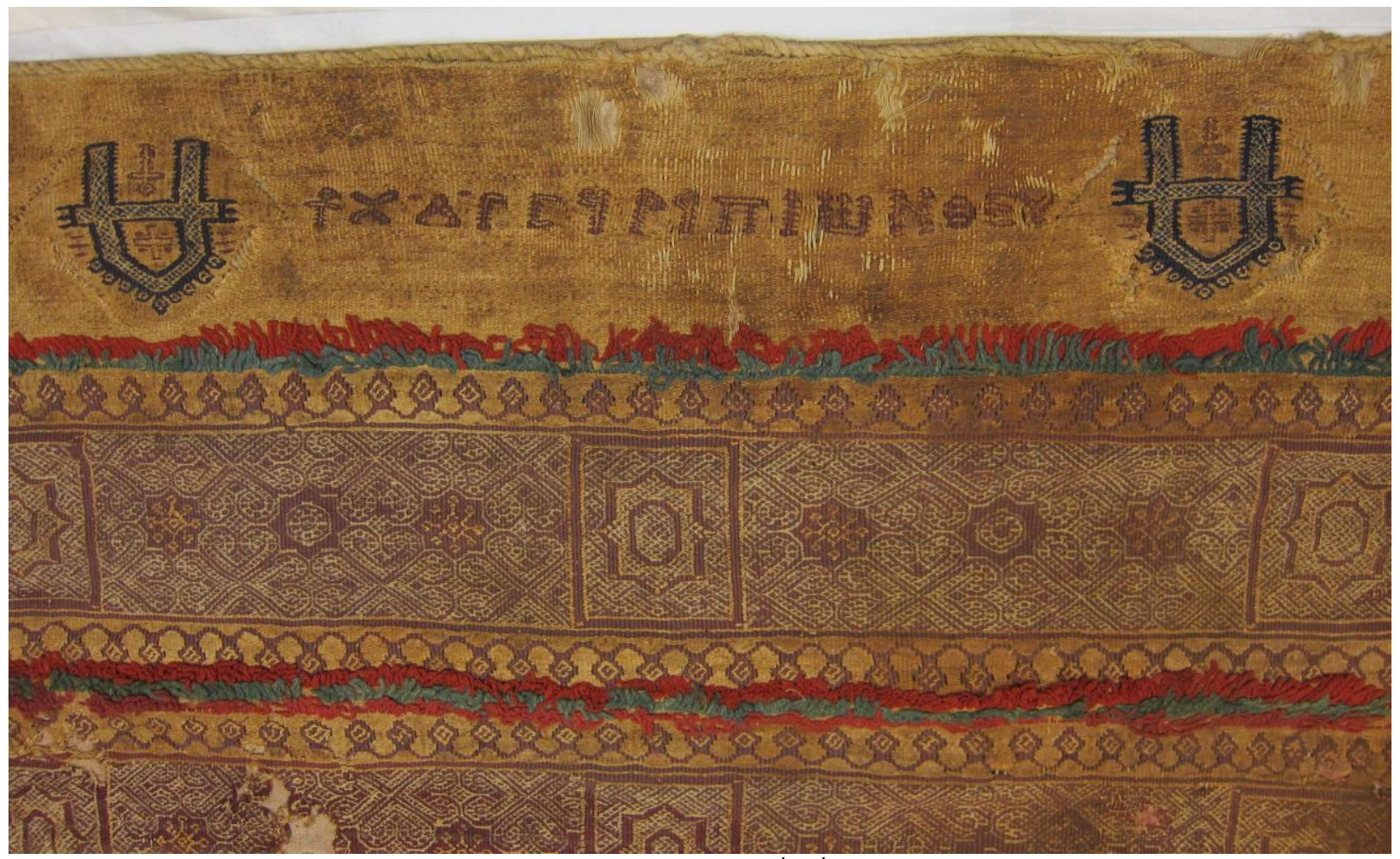

Tapestry inscription on textile shroud, Early Byzantine, from Egypt, $5^{\text {th }}-6^{\text {th }}$ century CE, linen and wool, Harvard Art Museum 1975.41.28, Gift of The Hagop Kevorkian Foundation in memory of Hagop Kevorkian, photo by author

After the initial staurogram in each inscription I read a set of three letters $-X, M$, and $\Gamma$ (chi, mu, and gamma) - that comprise an amuletic formula known in Christian inscriptions from the fourth century on. Its precise meaning is unknown and debated: the chi certainly references Christ, and the whole is usually interpreted as a Greek acrostic for some version of the phrase, "Christ, born

\footnotetext{
${ }^{5}$ Larry W. Hurtado, "The Staurogram in Early Christian Manuscripts: The Earliest Visual Reference to the Crucified Jesus?" in New Testament Manuscripts: Their Text and Their World, ed. Thomas J. Kraus and Tobias Nicklas (Leiden: Brill, 2006), 207-26.
} 
of Mary." ${ }^{\prime 6}$ Although the second letters in the chi-mu-gamma formulae on Harvard 1975.41.28 more closely resemble lambdas $(\Lambda)$, this variation does not preclude interpretation of the three letters as a reference to the common amuletic formula, nonstandard versions of which are well documented. ${ }^{7}$ Moreover, the truncation of one of the two inscriptions reveals that epigraphic inaccuracies are not out of the question; perhaps the weaver erroneously rendered only one half of a mu. The clarity of the chis and gammas, as well as the location of the three letters at the start of the inscriptions, argue in favor of their interpretation as a version of the chi-mu-gamma symbol.

The mysterious three-letter formula was undoubtedly apotropaic, and its inclusion here securely locates the textile within the tradition of protective inscriptions. This formula was carved over thresholds in homes, guarded the openings of vessels, and marked the beginnings and ends of amuletic inscriptions - all liminal spaces that might be especially vulnerable to magical attack. For example, inking the letters across the neck of a ceramic amphora defended the vessel's contents from the destructive force of envy. ${ }^{8}$ Use of the symbol in combination with personal names is exemplified on a wine sieve for the rite of the Eucharist, now in a private collection in Munich, marked with a votive inscription that twice repeats the three-letter formula in conjunction with a request for divine help for a certain Trophimos, a Eutychios, and their children. ${ }^{9}$ The formula's magical function is especially evident from its prominent place at the top of a papyrus amulet containing a binding spell requesting protection of a household from the Evil Eye in the name of Christ. ${ }^{10}$ Also featured along the bottom edge of the papyrus amulet are an alpha and omega flanking a cross, a staurogram, and an ankh-all symbols relevant to the iconographic program of 1975.41.28, as will be explored further below.

\footnotetext{
${ }^{6}$ Brent Nongbri, "The Lord's Prayer and ХМГ: Two Christian Papyrus Amulets," Harvard Theological Review (2011): 59-68; Stephen R. Llewelyn, "The Christian Symbol XMГ, an Acrostic or an Isopsephism?” in New Documents Illustrating Early Christianity, Volume 8: A Review of the Greek Inscriptions and Papyri Published 1984-85 (Grand Rapids, MI: Eerdmans, 1998), 156-68.

${ }^{7}$ Several versions are included in Nongbri, "The Lord's Prayer and ХМГ," esp. 67.

${ }^{8}$ This formula is present on the late-fourth-mid-fifth century amphora fragment in the British Museum (EA53955), found at Antinoöpolis.

${ }^{9}$ Ludwig Wamser, ed., Die Welt von Byzanz Europas östliches Erbe (Stuttgart: Theiss Verlag, 2004), 140-41, cat. no. 178. The inscription runs: + YПEP EYXHC TPOФIMOY KAI EYTYXIOY KAI TOY ПAIDIOY KYPIE $\mathrm{BOH \Theta I}+\mathrm{XM \Gamma}+\mathrm{XM} \Gamma+$

${ }^{10}$ P.Oslo I 5 (inv. 303), from Egypt, $4^{\text {th }}-5^{\text {th }}$ century.
} 


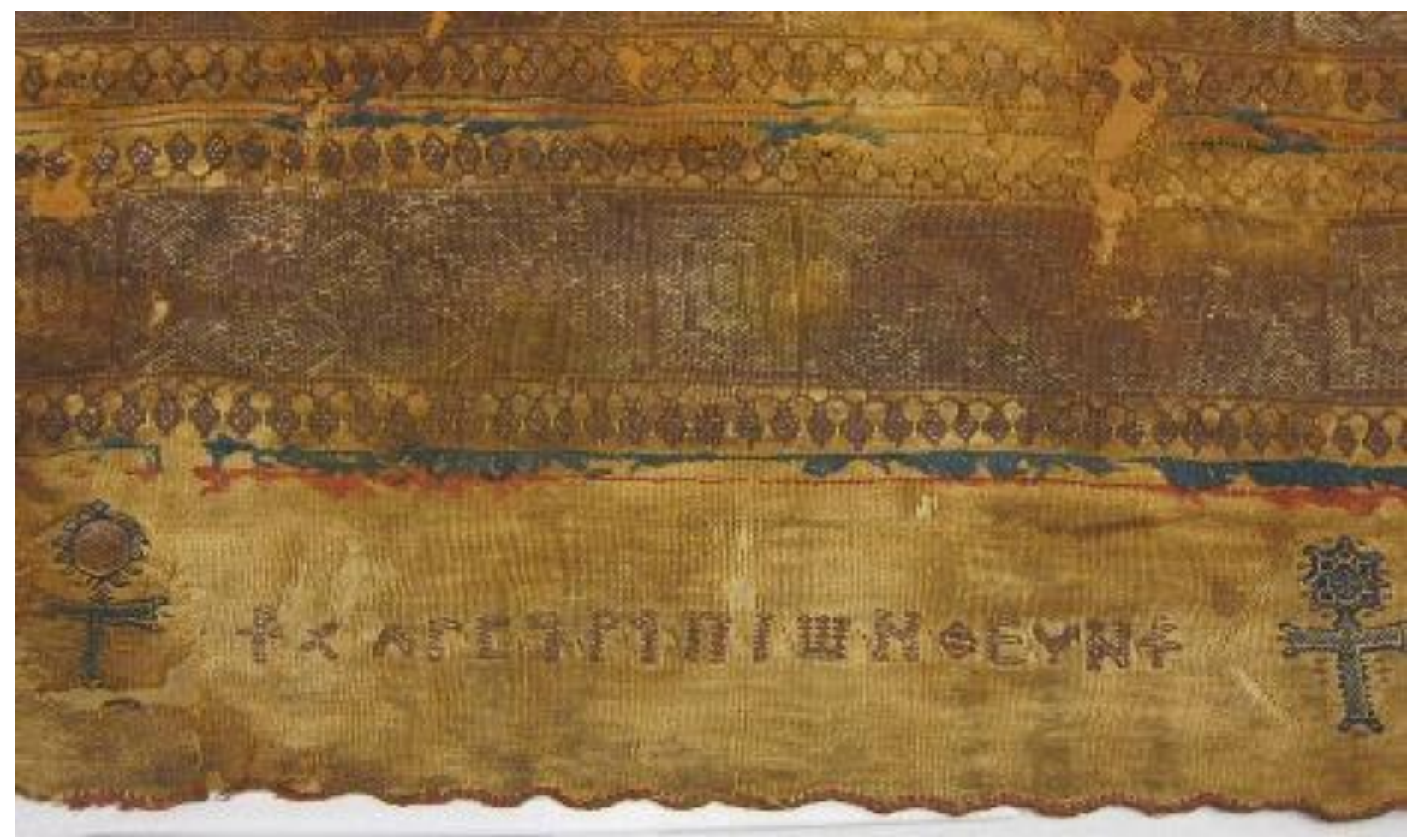

Tapestry inscription on textile shroud, Early Byzantine, from Egypt, $5^{\text {th }}-6^{\text {th }}$ century CE, linen and wool, Harvard Art Museum 1975.41.28, Gift of The Hagop Kevorkian Foundation in memory of Hagop Kevorkian, photo by author

Following this incipit of Christian symbols on the textile comes a double name. First, the name

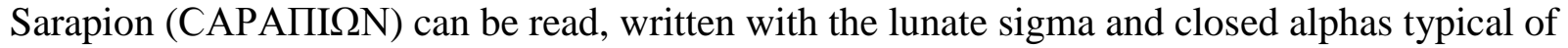
this period. This theophoric name, derived from the Ptolemaic god Serapis, survives into the Christian period and throughout Late Antiquity, primarily in connection with the cult of a martyr by this name. ${ }^{11}$ Next, the more complete of the two inscriptions gives a name that appears to be Theun $(\Theta E Y N)$ before the final staurogram. This unattested name is probably a variant or misspelling of the common Byzantine Egyptian name Theon ( $\Theta \dot{\varepsilon} \omega v)$. Thus, taken as a whole, the inscriptions combine staurograms, a Christian magical formula, and the double name Sarapion Theon.

The inclusion of names on textiles would have conveyed social status and perhaps served the practical function of marking donations to religious institutions. It is possible that Sarapion donated this textile to a church, though its heavy loop-pile would make it ill-suited to life as an altar cloth or niche curtain. While numerous inscribed votive gifts of other media survive, such as the bronze wine sieve mentioned above, the only secure example of a votive textile inscribed with names is the fine red and purple fragment from Oxyrhynchus that cites the expenses of a man, his wife, and children. ${ }^{12}$ A gift of textiles bearing donors' names is also recorded in the story of John and Sosiana in John of Ephesus' Lives of the Eastern Saints. ${ }^{13}$ Sarapion's textile,

\footnotetext{
${ }^{11}$ Willy Clarysse and Mario C. D. Paganini, "Theophoric Personal Names in Graeco-Roman Egypt: The Case of Sarapis," Archiv für Papyrusforschung und verwandte Gebiete 55.1 (2009): 68-89.

12 This fragment is Victoria and Albert Museum 277-1904. See Stephen Gaselee, "Lettered Egyptian Textiles in the Victoria and Albert Museum," Archaeologia 73 (1923): 73-84.

${ }^{13}$ English translation of the relevant passage available in E. W. Brooks, "John of Ephesus: Lives of the Eastern Saints (III)," in Patrologia Orientalis 19, ed. R. Graffin and F. Nau (Paris: Firmin-Didot, 1926), 194.
} 
though, while possibly a votive gift, above all was configured in its epigraphy and iconography to convey blessing and protection to this particular individual.

The profusion of propitious textual signs that form the remainder of the textile's decoration makes this clear. Purple and blue aniconic signs and letterforms, each enlivened with supplementary weft wrapping and embellished with surrounding dots and small crosses in contrasting colors, complement the larger areas of geometric patterning. Purple crosses occupy all four corners of the textile - an example of which is shown below. The three dots at the end of each arm, and the lattice of white supplementary yarns across the body, give each cross the appearance of a simplified crux gemmata. Crosses also mark each end of the double purple bands found near both ends of the textile, adding eight crosses to the four in the textile's corners.
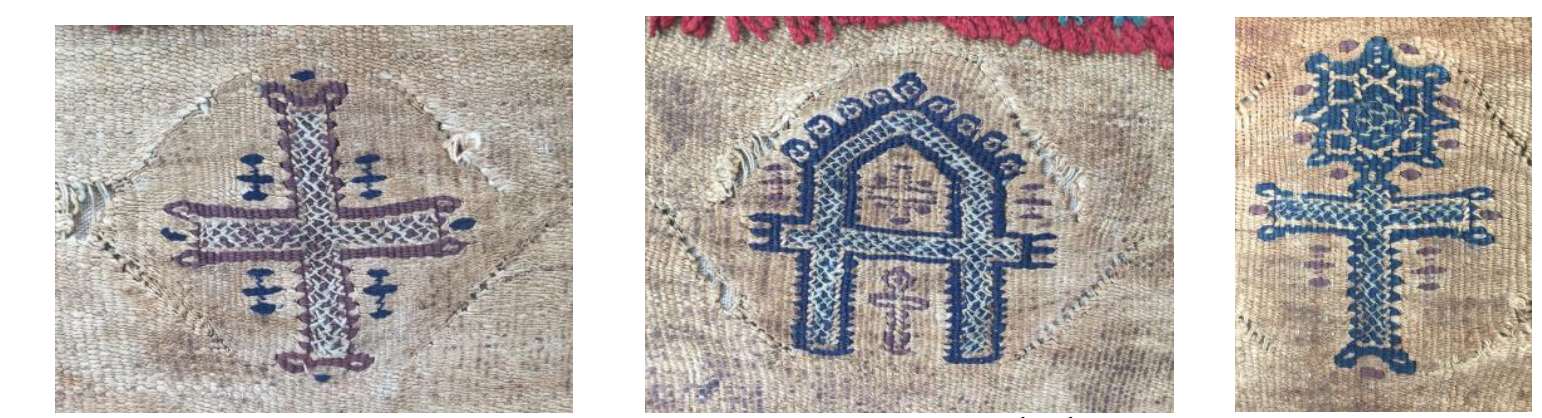

Details cross, alpha, and ankh on textile shroud, Early Byzantine, from Egypt, $5^{\text {th }}-6^{\text {th }}$ century CE, linen and wool, Harvard Art Museum 1975.41.28, Gift of The Hagop Kevorkian Foundation in memory of Hagop Kevorkian, photos by author

Two large blue ankhs (a symbol also referred to in a Christian context by the Latin term crux ansata) stand on either side of the lower inscription. The ankh was an Egyptian hieroglyph meaning "life" and associated with the god of death and regeneration, Osiris. The evident thematic parallel of life and rebirth, as well as its purely visual resemblance to the crucifix, made the ankh a significant symbol for Egyptian Christians. ${ }^{14}$ These woven ankhs are transformed from sleek textual signs by the application of color, outlining, and interlace, making them almost into images of jeweled, precious objects and hovering between linguistic and pictorial signification. ${ }^{15}$

More difficult to interpret is the pair of large blue symbols that resemble alphas on the other end of the textile. Curiously, their orientation is opposite to that of the inscription they flank. ${ }^{16}$ Each of these shapes contains purple crosses and ankhs and features small round projections along its upper edges. As on the crosses and ankhs, net-like supplementary weft wrapping fills the inner portions of the alpha-like shapes. The use of the alpha without the corresponding omega - in a

\footnotetext{
${ }^{14}$ Gillian E. Bowen, "The Crux Ansata in Early Christian Iconography: The Evidence from Dakhleh and Kharga Oases," in Le myrte et la rose: Mélanges offerts à Françoise Dunand par ses élèves, collègues et amis, ed. Gaëlle Tallet and Christiane Zivie-Coche (Montpellier: Université de Paul Valéry, 2014), 291-303.

${ }^{15}$ Although no jeweled ankhs survive from Late Antiquity, a fourth-century mummy portrait painted on linen depicts a richly dressed woman holding a gem-studded gold ankh in her left hand (Louvre AF6487, from Antinoöpolis). A slim gold ankh is held by the patrician woman depicted on Louvre AF 6440, another funerary shroud. Louvre AF 6488 shows a child holding an ankh, a dove, and a pomegranate.

${ }^{16}$ On a limestone stele in the Coptic Museum, Cairo (inv. no. 4302), the alphas alongside the central cross and in the inscription running along the upper edge of the stele are upside-down in relation to the rest of the textual and pictorial elements of the composition.
} 
letter-pair that combines the first and last letters of the Greek alphabet and metaphorically signifies the totality and limitlessness of God-is unusual and raises the question of whether the symbols on Harvard 1975.41.28 might be understood in another way.

Comparable visual elements occur on a small set of related textiles that also feature ankhs and interlace decoration. The quasi-architectural enhancements these 'alphas' receive on other textiles has led to their being interpreted as representations of the church façades or sacred niches that abound on Byzantine-era Egyptian funerary stelae and other media. ${ }^{17}$ The symbol on a textile fragment in the Detroit Institute of Arts, illustrated below, strays furthest from any resemblance to the letter alpha and further into the realm of the pictorial: the ends of its two legs splay into prongs, perhaps evoking column bases; the crossbar is exaggerated and extends far past the legs; and the sides of the upper portion swell outwards, as if suggesting a pointed dome topped with a finial. This purple shape, decorated with supplementary weft wrapping in yellow yarns, is additionally surrounded by a symmetrical arrangement of blue, red, and green birds that imbue the ambiguous image with a paradisial sense. Flattened, simplified, and suggestive, these architectural-alpha symbols, too, might reside somewhere between text and image.

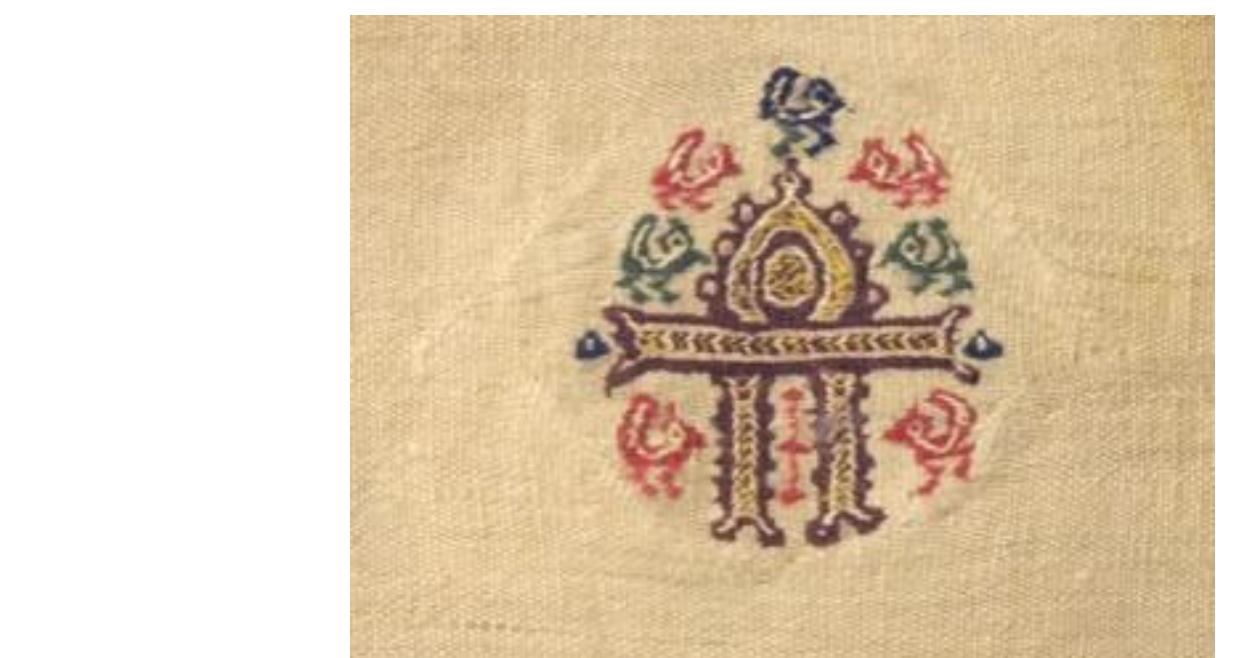

Detail of alpha-niche symbol, Early Byzantine, from Egypt, linen and wool, Detroit Institute of Arts 30.255, City of Detroit Purchase, photo in public domain

The crosses, ankhs, and 'alphas' on Harvard 1975.41.28 are contained within ogival shapes created by slivers of exposed warps. This subtle outline is also apparent on the dozen or so other textiles that display the architectural-alpha motif: eccentric wefts create a similar ogival shape around the symbol on the Detroit textile shown above, for example. This shared textural framing effect perhaps indicates some kind of common circumstances of production. Indeed, they are part of a small but distinct and likely interrelated group of textiles to which the Harvard piece belongs that take woven words and textual symbols for their primary decoration. Ornamented with letterforms created in brilliant colors, several of these objects are also inscribed with personal names. I will turn to some of these now to help further contextualize the Harvard textile.

\footnotetext{
${ }^{17}$ Pierre du Bourguet, "La fabrication des tissues coptes aurait-elle survécu à la conquête arabe?" Bulletin de la Société Archéologique d'Alexandrie 40 (1953): 11-31.
} 


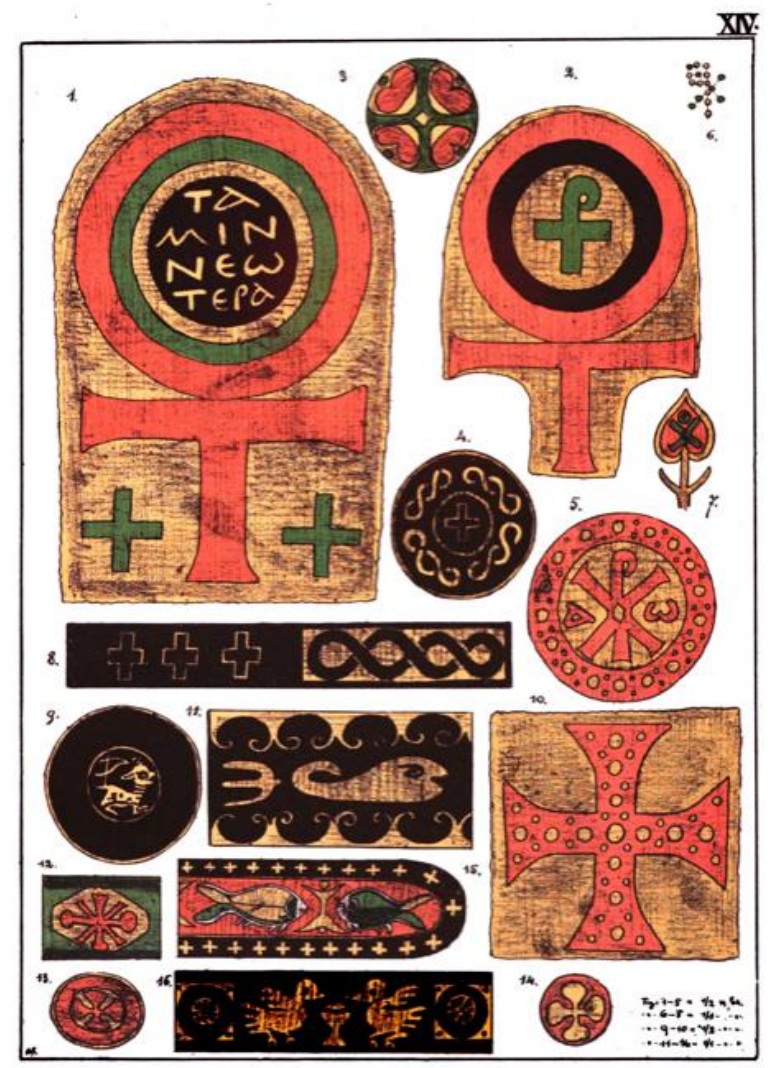

Robert Forrer, Die frühchristlichen Alterthümer aus dem Gräberfelde von Achmim-Panopolis (Strasbourg: F. Lohbauer, 1893), pl. 14, public domain

Robert Forrer's 1893 publication of textiles from the site of Akhmim (ancient Panopolis) illustrates a textile fragment that provides us with the name of a female individual. Plate 14 of the volume shows a fragment woven with a red ankh between twin green crosses. ${ }^{18}$ The current location of this piece is unknown to me, but its coloration was probably close to that of the ankh containing a staurogram illustrated on the same page in this volume and now in Berlin. ${ }^{19}$

The loop of the ankh contains several bold concentric circles centering on an inscription of Greek letters in four rows. The top two rows form the female name TAMIN (Tamin), an Egyptian name meaning "woman of the god Min." The green crosses make its Christian context obvious here, however. The bottom two rows of letters form the Greek epithet NESTEPA

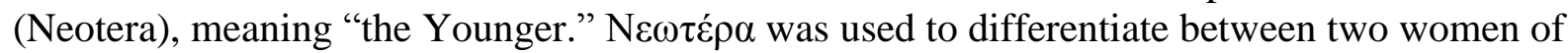
the same name who had a difference in age, with one being referred to as "the Elder" and the other as "the Younger." The term "the Younger" was also frequently used to designate newcomers to monastic communities. ${ }^{20}$

\footnotetext{
${ }^{18}$ Robert Forrer, Die frühchristlichen Alterthümer aus dem Gräberfelde von Achmim-Panopolis (Strasbourg: F. Lohbauer, 1893), pl. 14, fig. 1.

19 This is Staatliche Museen zu Berlin Ident. Nr. 9212.

${ }^{20}$ Rebecca Krawiec, Shenoute and the Women of the White Monastery (Oxford: Oxford University Press, 2002), 164. Jennifer Westerfeld remarks on the high proportion of female names accompanied by monastic titles or the epithet "the Younger" (in this case, UHM in Coptic) in graffiti at Abydos: "Monastic Graffiti in Context: The
} 
The use of such epithets to structure relationships within monastic "families" is attested notably at Shenoute of Atripe's White Monastery Federation, located just across the Nile from the site of Akhmim-Panopolis where this ankh tapestry was unearthed. Was Tamin the Younger a junior monk in Shenoute's women's community at Atripe? Were textiles that favor logographic decoration and the addition of personal names utilized in a monastic context? That can remain only speculation, and perhaps wild speculation at that. Let us consider another example.

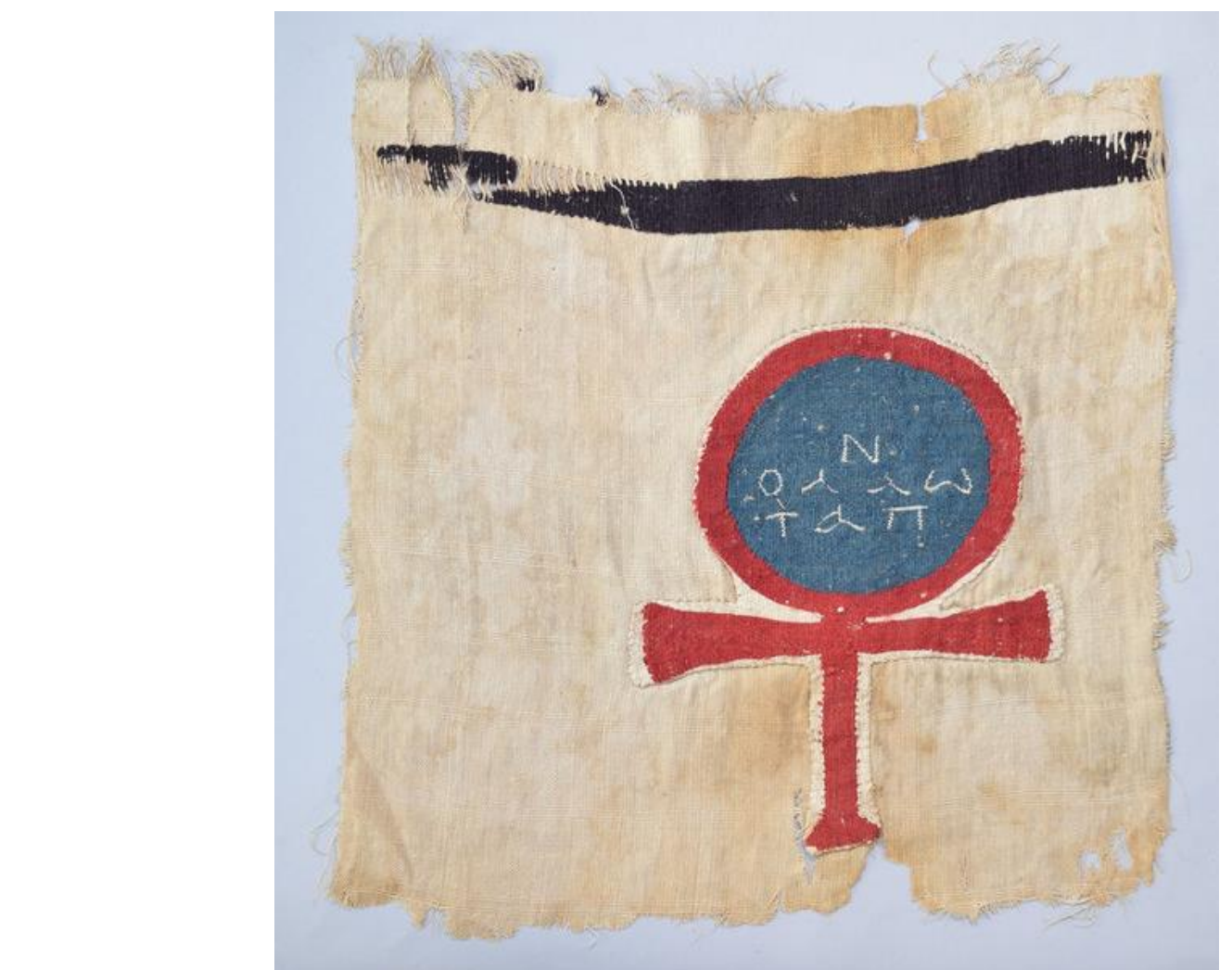

Tapestry ankh stitched onto linen backing, Early Byzantine, from Egypt, $4^{\text {th }}-5^{\text {th }}$ century, linen and wool, Victoria and Albert Museum 61-1897, photo (C) Victoria and Albert Museum, London

A red, tapestry-woven ankh has been cut from its original context and sewn onto a linen backing. ${ }^{21}$ Light blue fills the loop of the ankh and provides the background for a set of Greek letters. Unusually, the inscription reads from bottom to top, giving the Egyptian female name ТАПО $\Lambda \Lambda \Omega \mathrm{N}$ (Tapollon). This name, like Tamin, belongs to the type of Egyptian female name that combines the feminine definite article "Ta" with a divine name, meaning in this case, "the woman of Apollo." The incorporation of a Greek god into this traditional Egyptian naming format reflects Egypt's Hellenistic heritage. However, Tapollon and its variants are also documented as names borne by Christian women throughout Late Antiquity in Egypt. A certain Tapolle is in fact recorded in the copious writings of Shenoute, the famous monastic father at the

Temple of Seti I at Abydos," in Writing and Communication in Early Egyptian Monasticism, ed. Malcolm Choat and Maria Chiara Giord (Leiden: Brill, 2017), 187-212, at 201.

${ }^{21}$ This is Victoria and Albert Museum 61-1897. Discussed in Stephen Gaselee, "Lettered Egyptian Textiles in the Victoria and Albert Museum," Archaeologia 73 (1923): 73-84. 
White Monastery. ${ }^{22}$ This Tapolle was one of the women in charge of the monastery's weaving workshop that produced garments for both the men's and women's communities. ${ }^{23}$

Tapolle and Shenoute had an ongoing, well-documented conflict that sheds light on the character and production of textiles at the White Monastery. First, Tapolle and Shenoute quarreled over the monastic father's neglect of a special cloak that was made for him. A second disagreement between Shenoute and the weaver Tapolle arose over his dissatisfaction with the replacement cloak she and another female elder produced. ${ }^{24}$ Shenoute preferred his earlier cloak for its colors and decoration, which others had praised for their beauty. ${ }^{25} \mathrm{He}$ complains: "First of all, it is heavy on me. For, instead of attaching fringe to it, or [or setting] its tassels so that they will be spread apart, or so that when they get twisted or untwisted over time they will be entwined with the fringe, you have braided upon it like a tunic or a cloak."26

Far from the simple monastic garment we might imagine, Shenoute's cloak was evidently colorful, fringed, and decorated. Abbott Besa of this same monastery later decried as vain and improper the monks' practice of "embroidering" their garments, which he says they did in this monastery "with passion." ${ }^{27}$ David Frankfurter speculates on Besa's comment, arguing that it was unlikely for monks to be merely adding decorative pictures onto their garments. He writes, "One might imagine they were adding symbols that endowed their wearer with prestige or even apotropaic power." 28 Were these monks then adding textual signs and inscriptions like that found on the Harvard textile to their garments? In fact, we see the monks represented in the painted niches of the Red Monastery Church in Shenoute's Federation wearing cloaks with monograms of Greek or Coptic letters - another example of textual decoration on textiles. The wall painting of Shenoute, at this time dead and a saint in his own right, shows him wearing a cloak fastened over his chest with identical monograms on each shoulder. The same sign, illustrated below, also appears on the mantles of St. Besa, an unknown saint, and St. Bishay in this church.

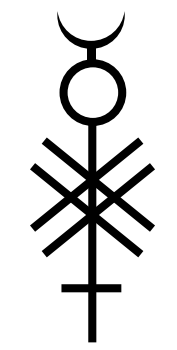

Textual symbol on mantles of Sts. Besa, Shenoute, Bishay, and an unknown saint, as painted in the Church of the Red Monastery, 500-525 CE, Egypt, line drawing: Sean Davidson

\footnotetext{
${ }^{22}$ For Tapolle, see Krawiec 42, 44-46, 61, 79, 82-86, 106, 110, 115, and 152.

23 Krawiec 46.

${ }^{24}$ For the neglect of the cloak: Krawiec 47, 202; for the dissatisfaction with the replacement cloak Krawiec 83-84, 202-203.

${ }^{25}$ White Monastery MONB.XO 63: ii.8-25, trans. Krawiec 202.

${ }^{26}$ White Monastery MONB.XO 66: i.1-30, trans. Krawiec 202.

${ }^{27}$ Besa, Ep., frag. 12, 5.2, 6.5, 8.4; ed. and trans. in K. H. Kuhn, Letters and Sermons of Besa (Louvain: Imprimerie orientaliste, 1956), 1.33-35, 2.32-33.

${ }^{28}$ David Frankfurter, Christianizing Egypt: Syncretism and Local Worlds in Late Antiquity (Princeton, NJ: Princeton University Press, 2017), 172-73.
} 
I do not include these anecdotes or painted representations to suggest that the weaver Tapolle was the same woman mentioned on the inscribed tapestry ankh, or that the garments she made would have resembled any of those under discussion here, but merely to help contextualize these textiles within the time, place, and cultural setting in which they originated.

To conclude, I would like to point forward in time to the use of text on the Islamic and Coptic tiraz fabrics that will accompany Harvard 1975.41.28 in the upcoming Social Fabrics exhibition. The emphasis on personal names in Christian amuletic inscriptions persists in the artistic products of the Christian community in Egypt well after the Islamic conquest. The banded decoration and red lettering on a textile fragment from Dumbarton Oaks offer stylistic parallels to the Islamic tiraz in the exhibition and demonstrate the influence of the tiraz fashion in the wider Egyptian community. Like the tiraz that wish for blessings for their wearers, the woven letters on the Dumbarton Oaks textile spell out a plea for divine help. The Coptic-language inscription, though, is explicitly Christian, reading: "Come to my aid, oh Jesus Christ; I (am) the priest Victor son of Meus." ${ }^{29}$ In keeping with pre-Islamic amuletic traditions, the full name and, in this case, even parentage and occupation of the individuals are specified to ensure the request would be correctly understood. Islamic tiraz, in contrast, leave their recipients anonymous but supply the name of the ruling caliph, vizier, or other administrator, as well as sometimes a location and date. Jochen Sokoly has argued that such tiraz transmit a blessing by forming a material statement of the recipient's allegiance to the caliph.$^{30} \mathrm{He}$ suggests that the tiraz, wrapped around the body of the deceased, may thus have helped distinguish believer from nonbeliever on the day of judgment.

These differences in Christian and Islamic inscribing practice are rooted in different approaches and attitudes to the conveyances of blessings, though both traditions attest to the suitability of textiles as vehicles for expressing personal hopes for good fortune and divine care of the soul.

\footnotetext{
${ }^{29}$ Elizabeth Dospěl Williams and Marek Dospěl, "Fragment with Coptic Inscription, BZ.1953.2.3," catalogue entry, May 2019, in Catalogue of the Textiles in the Dumbarton Oaks Byzantine Collection, ed. Gudrun Bühl and Elizabeth Dospěl Williams (Washington, DC, 2019), https://www.doaks.org/resources/textiles/catalogue/BZ.1953.2.3.

30 Jochen Sokoly, "Textiles and Identity," in A Companion to Islamic Art and Architecture, ed. Finbarr Barry Flood and Gülru Necipoğlu (Hoboken, NJ: Wiley-Blackwell, 2017), 275-99.
} 


\section{$\underline{\text { Bibliography }}$}

Ball, Jennifer. "Charms: Protective and Auspicious Motifs." In Designing Identity: The Power of Textiles in Late Antiquity, edited by Thelma K. Thomas, 54-65. Princeton, NJ: Princeton University Press, 2016.

Bourguet, Pierre du. "La fabrication des tissues coptes aurait-elle survécu à la conquête arabe?" Bulletin de la Société Archéologique d'Alexandrie 40 (1953): 11-31.

Bowen, Gillian E. "The Crux Ansata in Early Christian Iconography: The Evidence from Dakhleh and Kharga Oases." In Le myrte et la rose: Mélanges offerts à Françoise Dunand par ses élèves, collègues et amis, edited by Gaëlle Tallet and Christiane ZivieCoche, 291-303. Montpellier: Université de Paul Valéry, 2014.

Brooks, E. W., trans. "John of Ephesus: Lives of the Eastern Saints (III)." In Patrologia Orientalis 19, edited by R. Graffin and F. Nau, 151-619. Paris: Firmin-Didot, 1926.

Clarysse, Willy and Mario C. D. Paganini. "Theophoric Personal Names in Graeco-Roman Egypt: The Case of Sarapis." Archiv für Papyrusforschung und verwandte Gebiete 55.1 (2009): 68-89.

Dauterman Maguire, Eunice. "Curtains at the Threshold: How They Hung and How They Performed." In Catalogue of the Textiles in the Dumbarton Oaks Byzantine Collection, edited by Gudrun Bühl and Elizabeth Dospěl Williams. Washington, DC, 2019. https://www.doaks.org/resources/textiles/essays/maguire.

Dospěl Williams, Elizabeth, and Marek Dospěl. "Fragment with Coptic Inscription, BZ.1953.2.3." Catalogue entry, May 2019. In Catalogue of the Textiles in the Dumbarton Oaks Byzantine Collection, edited by Gudrun Bühl and Elizabeth Dospěl Williams.

Washington, DC, 2019. https://www.doaks.org/resources/textiles/catalogue/BZ.1953.2.3.

Forrer, Robert. Die frühchristlichen Alterthümer aus dem Gräberfelde von Achmim-Panopolis. Strasbourg: F. Lohbauer, 1893.

Frankfurter, David. Christianizing Egypt: Syncretism and Local Worlds in Late Antiquity. Princeton, NJ: Princeton University Press, 2017.

Gaselee, Stephen. "Lettered Egyptian Textiles in the Victoria and Albert Museum." Archaeologia 73 (1923): 73-84.

Graf, Fritz. Magic in the Ancient World. Translated by Franklin Philip. Cambridge, MA: Harvard University Press, 1997.

Hurtado, Larry W. "The Staurogram in Early Christian Manuscripts: The Earliest Visual Reference to the Crucified Jesus?" In New Testament Manuscripts: Their Text and Their World, edited by Thomas J. Kraus and Tobias Nicklas, 207-26. Leiden: Brill, 2006.

Krawiec, Rebecca. Shenoute and the Women of the White Monastery. Oxford: Oxford University Press, 2002.

Kuhn, K. H., ed. and trans. Letters and Sermons of Besa. Louvain: Imprimerie orientaliste, 1956. Llewelyn, Stephen R. "The Christian Symbol XMГ, an Acrostic or an Isopsephism?" In New Documents Illustrating Early Christianity 8: A Review of the Greek Inscriptions and Papyri Published 1984-85, edited by Stephen R. Llewelyn, 156-68. Grand Rapids, MI: Eerdmans, 1998.

Maguire, Henry, ed. Byzantine Magic. Washington, DC: Dumbarton Oaks Research Library and Collection, 1995.

Nongbri, Brent. "The Lord's Prayer and ХМГ: Two Christian Papyrus Amulets." Harvard Theological Review (2011): 59-68. 
Sokoly, Jochen. "Textiles and Identity." In A Companion to Islamic Art and Architecture, edited by Finbarr Barry Flood and Gülru Necipoğlu, 275-99. Hoboken, NJ: Wiley-Blackwell, 2017.

Spier, Jeffrey. "Medieval Byzantine Magical Amulets and Their Tradition." Journal of the Warburg and Courtauld Institutes 56 (1993): 25-62.

Van der Vliet, Jacques. "'In a Robe of Gold': Status, Magic and Politics on Inscribed Christian Textiles from Egypt." In Textile Messages: Inscribed Fabrics from Roman to Abbasid Egypt, edited by Cäcilia Fluck and Gisela Helmecke, 23-67. Leiden: Brill, 2006.

Wamser, Ludwig, ed. Die Welt von Byzanz Europas östliches Erbe. Stuttgart: Theiss Verlag, 2004.

Westerfeld, Jennifer. "Monastic Graffiti in Context: The Temple of Seti I at Abydos." In Writing and Communication in Early Egyptian Monasticism, edited by Malcolm Choat and Maria Chiara Giord, 187-212. Leiden: Brill, 2017. 